\title{
RANCANG BANGUN APLIKASI SISTEM INFORMASI PARIWISATA KABUPATEN TANAH KARO DENGAN API GOOGLE MAPS BERBASIS ANDROID
}

\author{
* Ricky Andrean Sitepu ${ }^{1},{ }^{*}$ Yonata $\mathrm{Laia}^{2},{ }$ Andreas Brehme Silalahi ${ }^{3}$,Tri Dedi Sibarani ${ }^{4}$ \\ Program Studi Sistem Informasi Fakultas Teknologi dan Ilmu Komputer Universitas Prima Indonesia \\ E-mail : *tepoe.ricky@gmail.com
}

\begin{abstract}
ABSTRAK- Tanah Karo adalah salah satu kabupaten yang terdapat di Provinsi Sumatera Utara yang memiliki potensi wisata yang sangat menjanjikan dan menjadikan pariwisata sebagai salah satu Pendapatan Asli Daerah (PAD). Pada awal tahun 2017 terdapat kunjungan wisatawan sebanyak 22.781 kunjungan akan tetapi pada awal tahun 2018 terdapat penurunan menjadi 22.055 kunjungan wisatawan. Dengan kemajuan teknologi yang sudah sangat pesat maka dimungkinkannya menciptakan sebuah aplikasi yang menggunakan sistem operasi android dengan menggunakan metode Waterfall . Dengan memanfaatkan teknologi API Google Maps, aplikasi ini memberikan arah direksi perjalanan lokasi objek wisata serta mempermudah wisatawan dalam menentukan pilihan obyek wisata yang akan dikunjungi dengan memberikan referensi objek - wisata, memberikan informasi berupa foto dari obyek sejarah maupun artikel dari obyek wisata, tarif biaya masuk, menampilkan ulasan maupun komentar dari obyek wisata.
\end{abstract}

Kata kunci : Pariwisata, Android, API Google Maps.

\section{PENDAHULUAN}

Pariwisata merupakan salah satu hal yang penting bagi suatu negara. Dengan adanya pariwisata, suatu negara atau lebih khususnya lagi pemerintah daerah tempat wisata itu berada mendapat pemasukan dari pendapatan setiap objek wisata [1].

Potensi pariwisata yang terdapat di Provinsi Sumatera Utara sangatlah indah dan luas didukung dengan keberagaman seni budaya serta ketersediaan sarana dan prasarana yang sangat dapat mendukung bidang pariwisata yang dapat menjadi roda penggerak ekonomi masyarakat. Tanah Karo sebagai salah satu kabupaten yang terdapat di Provinsi Sumatera Utara yang memiliki mayoritas Suku Karo dengan budaya yang masih dijaga dengan baik sampai sekarang telah lama dikenal sebagai salah satu kabupaten yang memiliki potensi wisata yang sangat menjanjikan dan menjadikan pariwisata sebagai salah satu Pendapatan Asli Daerah (PAD). Kabupaten Tanah Karo secara geografis berada pada ketinggian 200 - 1.500 meter diatas permukaan laut. Sebelah Utara Kabupaten Tanah Karo berbatasan dengan Kabupaten Langkat dan Kabupaten Deli Serdang, sebelah Selatan berbatasan dengan Kabupaten Dairi dan Toba Samosir, sebelah Timur dengan Kabupaten Deli Serdang dan Simalungun dan sebelah Barat dengan Provinsi Nanggroe Aceh Darussalam [2].

Akan tetapi berdasarkan data yang diperoleh, terlihat beberapa penurunan kunjungan wisatawan yang berkunjung ke Kabupaten Tanah Karo. Seperti pada awal tahun 2017 terdapat kunjungan wisatawan sebanyak 22.781 kunjungan, akan tetapi pada awal tahun 2018 terdapat penurunan menjadi 22.055 kunjungan wisatawan yang mengunjungi kabupaten yang berada di dataran tinggi yang terkenal dengan gunung Sinabung ini [3].

Saat ini kemajuan teknologi yang sudah sangat pesat maka dimungkinkannya menciptakan sebuah aplikasi yang menggunakan sistem operasi android yang dapat mempromosikan atau menginformasikan daya tarik objek - objek wisata yang terdapat di Kabupaten Tanah Karo sehingga diharapkan dapat meningkatkan minat pengunjung untuk berwisata ke Kabupaten Tanah Karo.

Dengan memanfaatkan teknologi API Google Maps, aplikasi dapat memberikan arah direksi perjalanan menuju lokasi objek wisata. API Google Maps adalah sebuah layanan yang diberikan oleh Google dalam memetakan suatu tempat dengan menggunakan aplikasi Google Maps [4][8].

Aplikasi juga dapat mempermudah wisatawan dalam menentukan pilihan obyek wisata yang dapat dikunjungi dengan memberikan referensi objek objek wisata yang terdapat di Kabupaten Tanah Karo yang dapat dikunjungi, memberikan informasi berupa foto dari obyek wisata, sejarah maupun artikel dari obyek wisata, tarif biaya masuk, menampilkan ulasan maupun komentar dari obyek wisata.Aplikasi tersebut dapat digunakan pada smartphone sehingga mudah digunakan dan diharapkan tingkat kunjungan para wisatawan yang berkunjung Kabupaten Tanah Karo semakin meningkat.

\section{ISI PENELITIAN}

\subsection{Metode Penelitian Waterfall}

Metode penelitian yang diterapkan pada penelitian ini adalah dengan pengembangan metode Waterfall. Metode Waterfall adalah model air terjun yang menyediakan pedekatan alur hidup perangkat lunak secara sekuensial atau terurut [5]. 
Adapun tahapan - tahapan yang dilakukan dalam penelitian ini adalah sebagai berikut :

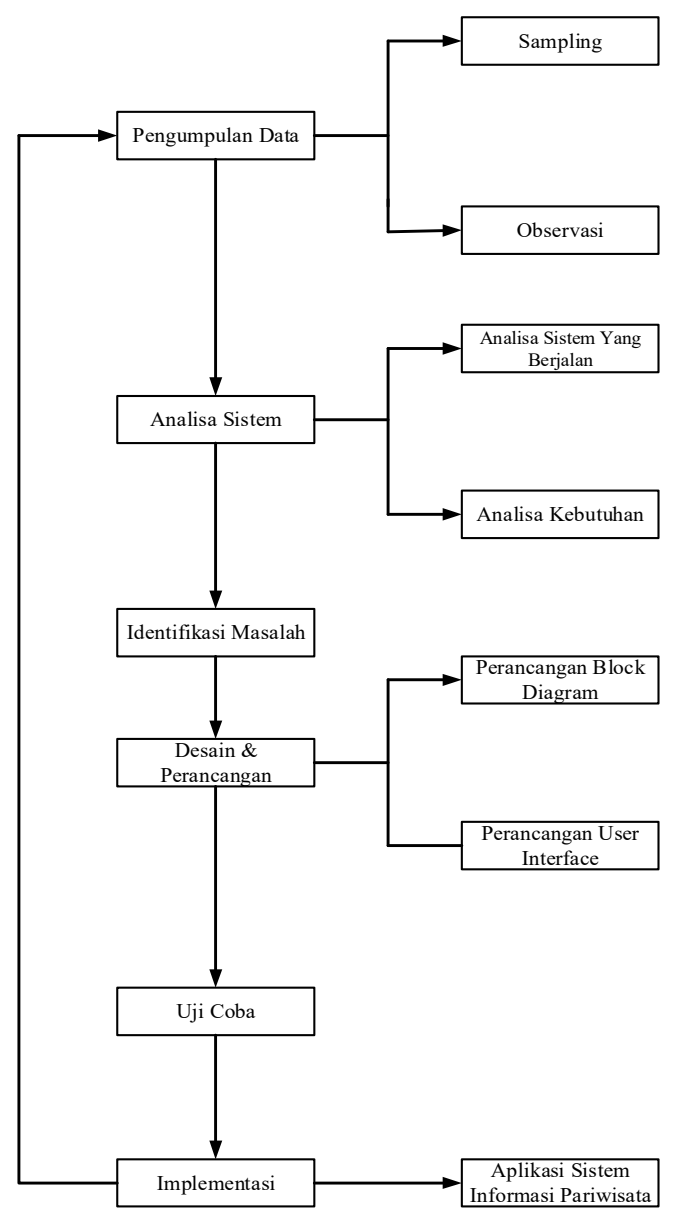

\section{Gambar 1. Metode Peneltian Waterfall Sistem}

Gambar 1 menjelaskan metode penelitian dari aplikasi yang akan dirancang tersebut pada awalnya yang dilakukan adalah pengumpulan data berdasarkan kebutuhan sistem pariwisata dengan melakukan Sampling datadan Observasi terhadap obyek - obyek wisata yang akan di input kedalam sistem. Berikutnya yaitu menganalisis sistem yang sudah berjalan pada website pariwisata pemerintah kabupaten Tanah Karo.

Selanjutnya perancangan sistem dengan menggunakan Block Diagram serta merancang desain User Interface sistem. Rancang bangun sistem akan menggunakan sistem operasi berbasis android dan sistem web sebagai server dari sistem tersebut. Sistem akan diuji dan akan dilakukan testing pada aplikasi sistem informasi parawisata sampai aplikasi bekerja sesuai dengan keinginan maka akan diimplementasikan dan digunakan oleh pengguna untuk mencari referensi obyek wisata atau petunjuk arah menuju lokasi obyek wisata dan segera dilakukan pengambilan kesimpulan dan pengembangan untuk sistem kedepannya.

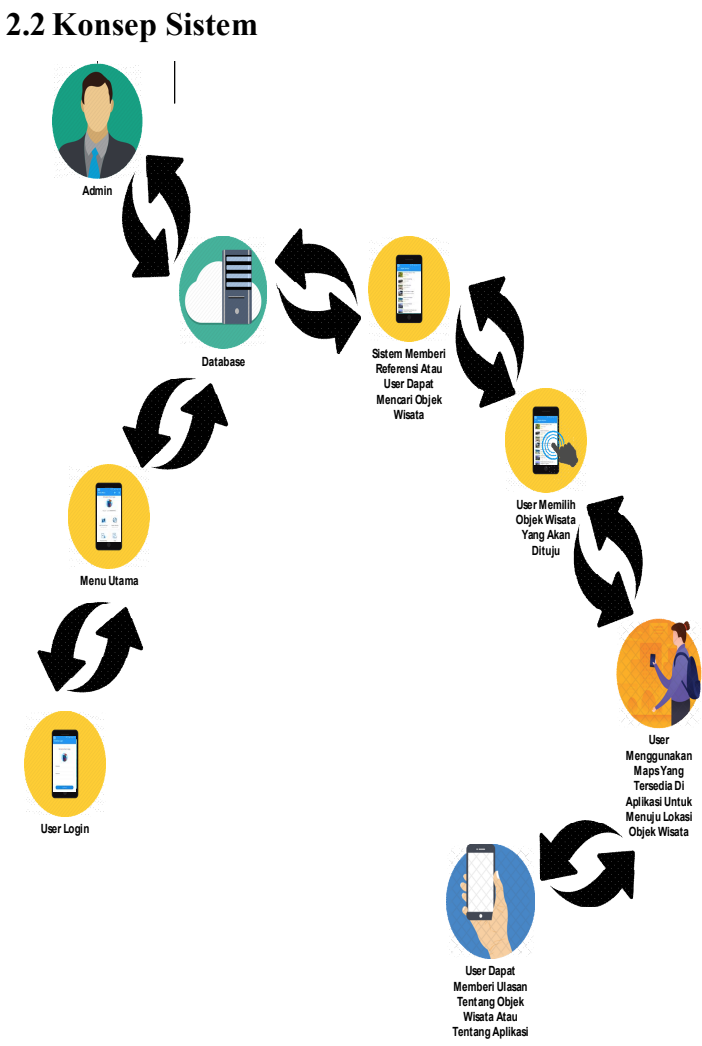

Gambar 2. Konsep Sistem

Gambar 2 Dari gambaran umum sistem yang terdapat diatas maka dapat terlihat pengguna dengan menggunakan smartphone terlebih dahulu melakukan login ke aplikasi, jika login berhasil maka pengguna akan masuk ke beranda aplikasi dari sistem informasi pariwisata dan pengguna dapat memilih objek wisata yang diinginkan. apabila telah menentukan objek wisata maka pengguna dapat menggunakan bantuan maps jika tidak mengetahui lokasi wisata yang ingin dituju.

Setelah sampai tujuan objek wisata maka pengguna dapat memberi ulasan nilai tentang objek wisata dan pengguna juga dapat mengirim saran kepada admin jika terdapat kekurangan pada aplikasi atau memberi referensi objek wisata yang belum terdapat pada aplikasi dengan mengunakan fitur kotak saran yang terdapat pada aplikasi. Hasil nilai objek wisata yang diberi pengguna akan disimpan ke dalam database dan akan ditampilkan di aplikasi sebagai referensi untuk pengguna lainnya. Admin akan melakukan pengecekan saran dari pengguna tentang aplikasi sehingga saran yang masuk dan dapat digunakan sebagai referensi update aplikasi kedepannya agar diharapkan aplikasi menjadi lebih baik.

\subsection{Perancangan Database}

Rancangan database ini berisi relasi antara tabel yang saling berkaitan pada Rancang Bangun Aplikasi Sistem Informasi Pariwisata Kabupaten 
Tanah Karo Dengan API Google Maps Berbasis Android. Tampilan database dapat dilihat seperti pada gambar berikut :

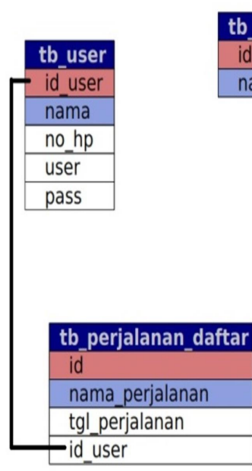

\section{Gambar 3. Relasi Database}

\subsection{Perancangan Use Case Diagram}

Perancangan use case diagram digunakan dalam menggambarkan yang dapat dilakukan oleh sistem dan menggambarkan peran serta user dalam berinteraksi dengan sistem. Berikut merupakan use case diagram dari Rancang Bangun Aplikasi Sistem Informasi Pariwisata Kabupaten Tanah Karo Dengan API Google Maps Berbasis Android:

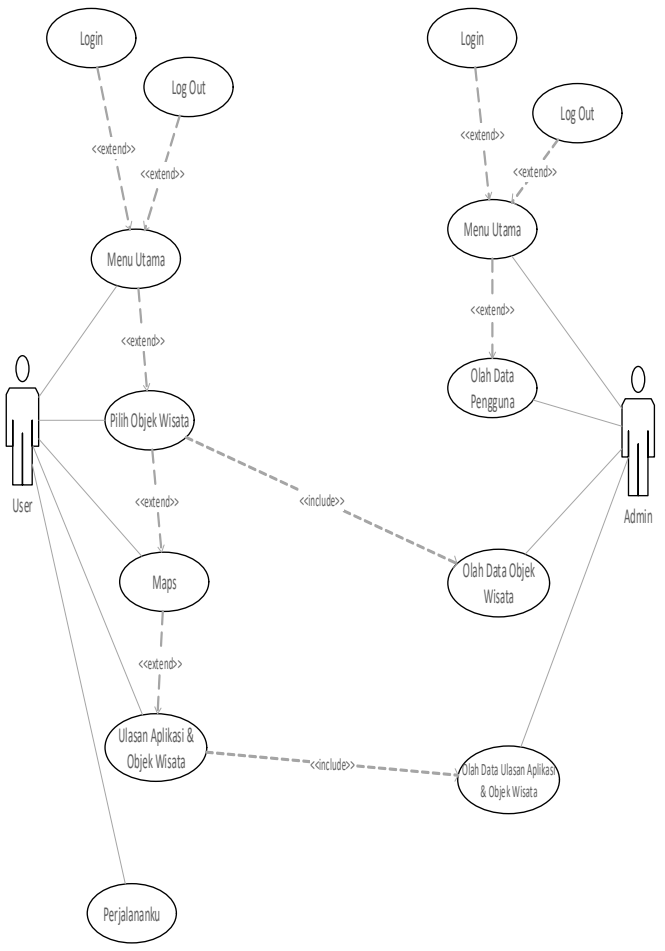

Gambar 4. Use Case Diagram Sistem

\subsection{Perancangan Activity Diagram}

Dalam memodelkan alur dari sistem maka digunakan perancangan dengan pemodelan activity diagram. Activity diagram juga dapat mengambarkan interaksi dari beberapa use case. Berikut ini merupakan activity diagram dari Rancang Bangun Aplikasi Sistem Informasi Pariwisata Kabupaten Tanah Karo Dengan API Google Maps Berbasis Android :

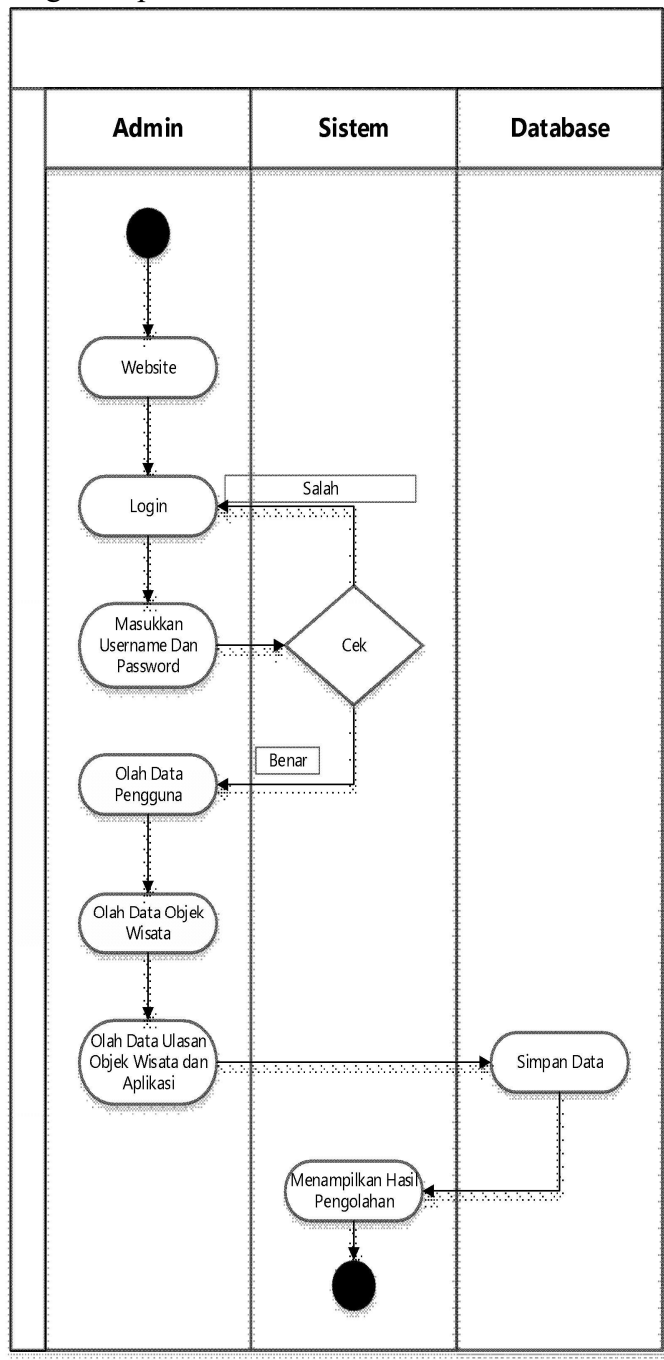

Gambar 5. Activity Diagram Admin

Dalam proses Activity Diagram Admin, admin terlebih dahulu membuka website admin dan melakukan login. Setelah login, admin dapat melakukan pengolahan data pengguna, olah data objek wisata dan melihat saran yang dikirim oleh pengguna. 


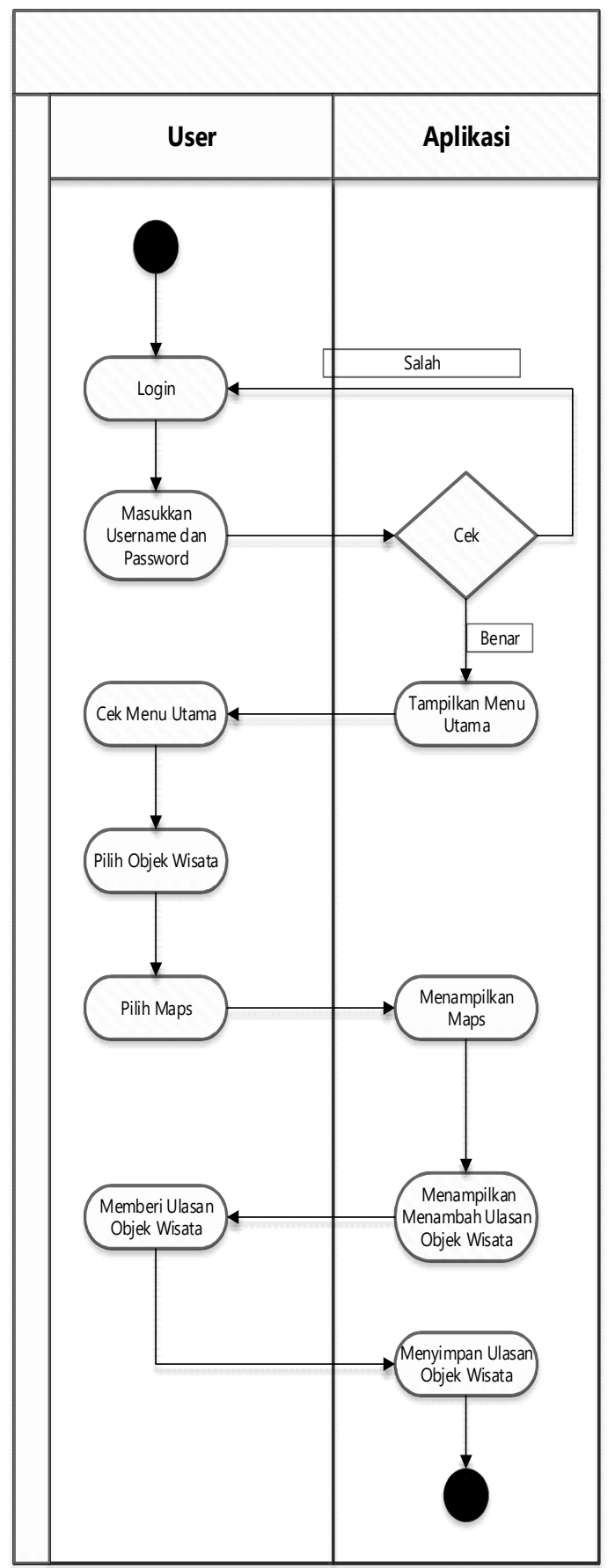

Gambar 6. Activity Diagram User

Pada Activity Diagram User, terlebih dahulu user melakukan login pada aplikasi, setelah login berhasil maka user dapat mengakses menu utama aplikasi, user dapat memilih objek wisata yang diinginkan untuk dikunjungi dan menggunakan maps dalam direksi perjalanan menuju lokasi objek wisata, user juga dapat memberi nilai tentang objek wisata yang telah dikunjungi.

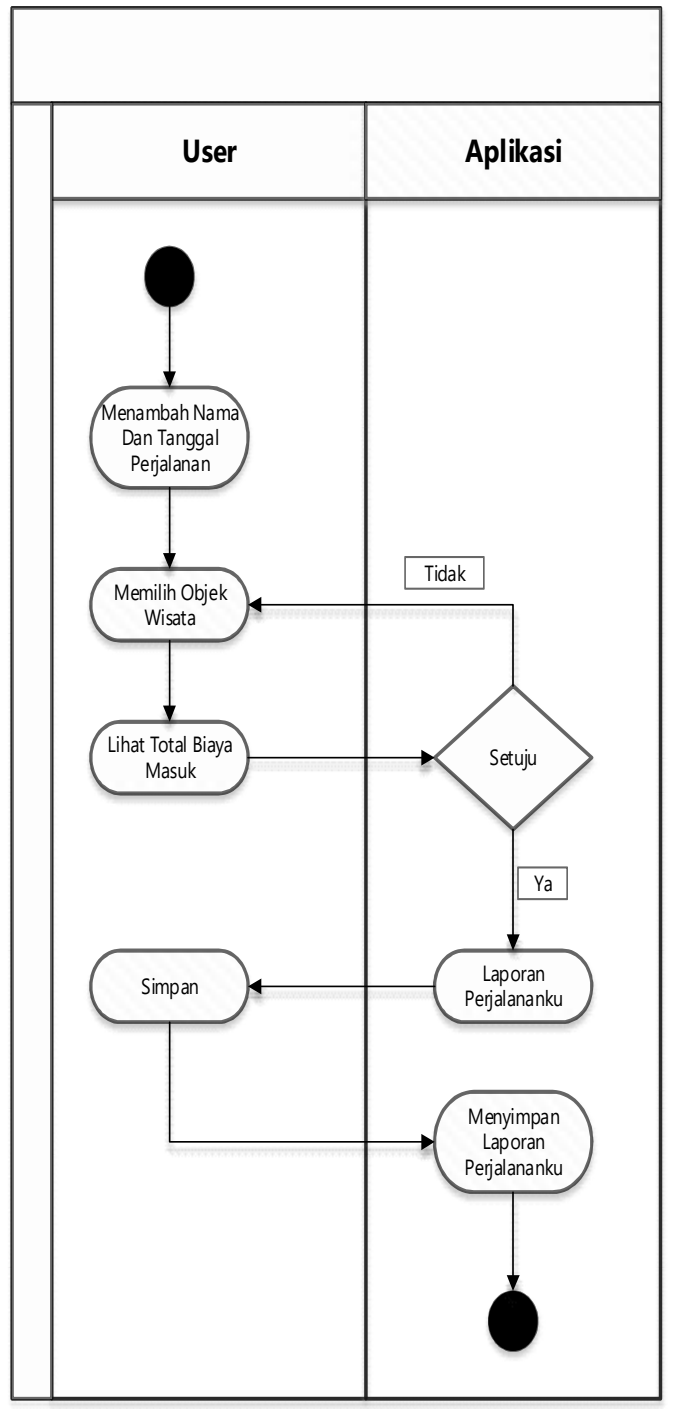

Gambar 7. Activity Diagram Perjalananku

Dalam proses Activity Diagram Perjalananku, user terlebih dahulu menambahkan nama dan tanggal perjalanan. Setelah menambahkan nama dan tanggal perjalanan maka user dapat memilih objek wisata yang ingin dikunjungi, setelah memilih beberapa objek wisata yang ingin dikunjungi maka user akan dapat melihat jumlah hasil total perjanan biaya masuk objek wisata yang telah dipilih. Jika user telah menyetujui total biaya masuk objek wisata maka user dapat menyimpan perjalananku dan jika user tidak menyetujui total biaya masuk objek wisata maka user dapat memilih objek wisata lainnya sampai sesuai dengan total biaya masuk yang di inginkan oleh user 
Jurnal Sistem Informasi dan Ilmu Komputer Prima (JUSIKOM PRIMA)

Vol. 3 No. 1, Agustus 2019

e-ISSN : 2580-2879

\section{Hasil dan Pembahasan}

Berikut ini merupakan tampilan hasil implementasi antroid dan web pada aplikasi sistem informasi pariwisata Kabupaten Tanah Karo.

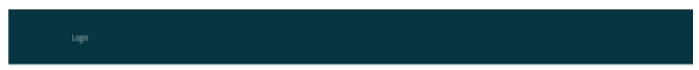

Login

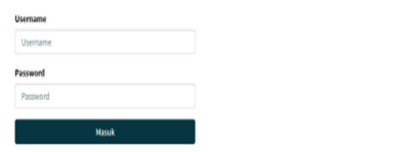

\section{Gambar 8. Tampilan Halaman Login Web}

Halaman ini merupakan halaman login admin untuk masuk ke web server. Setelah berhasil login maka admin akan masuk ke halaman utama web server.

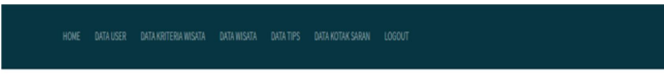

Beranda

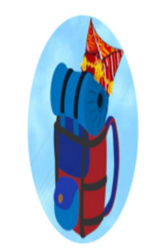

Selamat Datang di Wista Karo

\section{Gambar 9. Tampilan Halaman Utama $\mathrm{Web}$}

Pada halaman ini ditampilkan beberapa menu utama untuk mengolah data yang terdapat pada sistem.

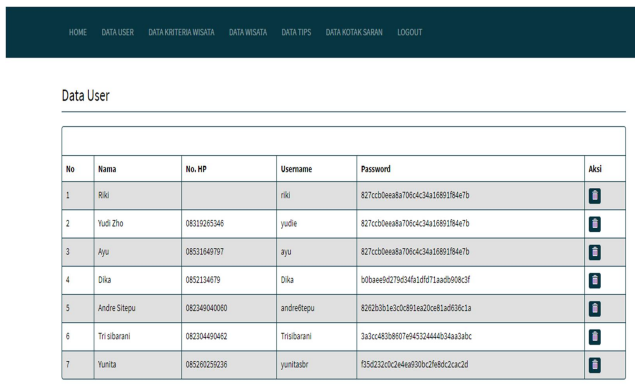

Gambar 10. Tampilan Halaman Pengolahan Data User

Pada halaman ini admin dapat mengolah data user dan melihat informasi user
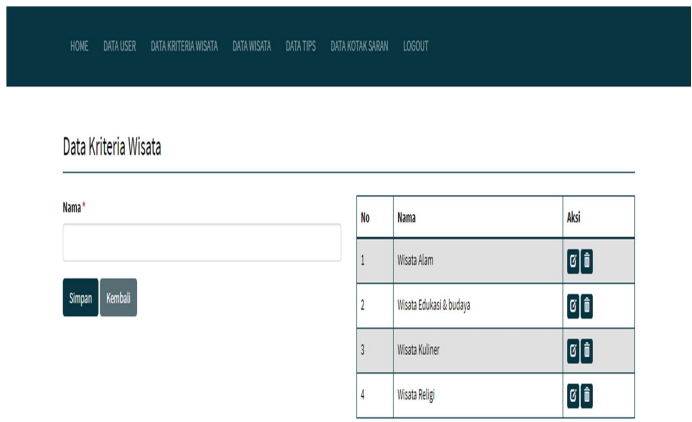

Gambar 11. Tampilan Halaman Pengolahan Data Kriteria Wisata

Halaman ini merupakan halaman login admin untuk masuk ke web server. Setelah berhasil login maka admin akan masuk ke halaman utama web server.

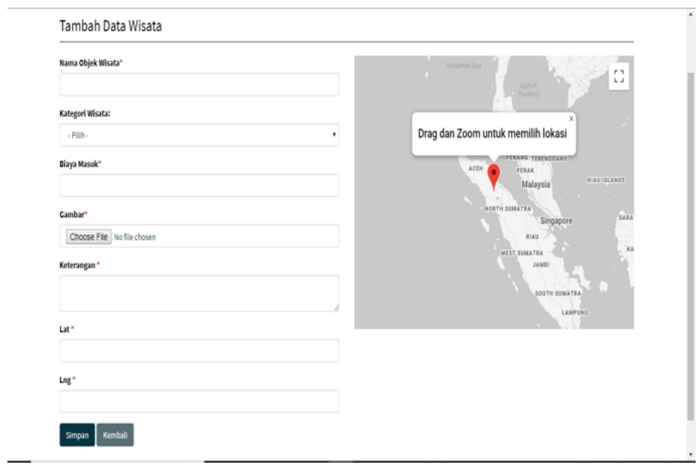

Gambar 12. Tampilan Halaman Tambah Objek Wisata

Halaman ini merupakan penambahan objek wisata yang akan ditampilkan pada aplikasi.

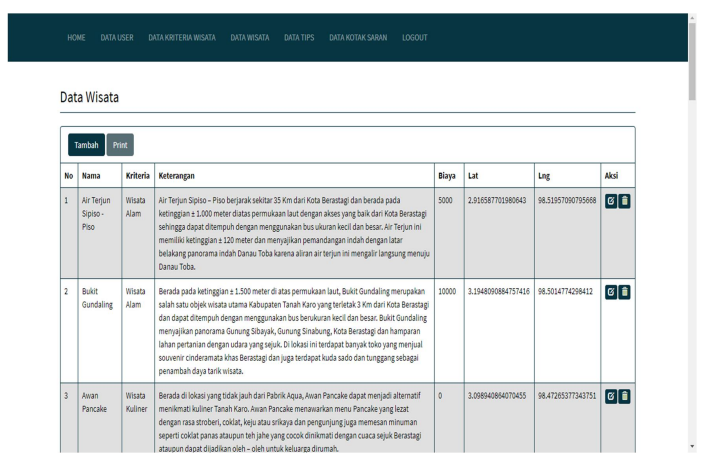

Gambar 13. Tampilan Halaman Data Wisata

Halaman ini merupakan pengolahan data dari objek wisata yang akan ditampilkan di aplikasi android. Pengolahan data berupa menambah objek 
wisata, mengubah objek wisata atau menghapus objek wisata.

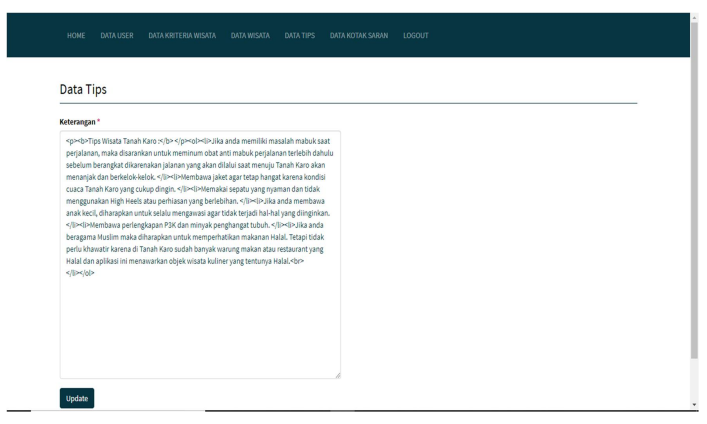

Gambar 14. Tampilan Halaman Data Tips

Pada halaman ini bertujuan mengisi data tips yang akan ditampilkan di aplikasi dengan tujuan untuk memberi saran kepada user dalam berwisata ke Kabupaten Tanah Karo sehingga dapat menghindari hal - hal yang tidak diinginkan.

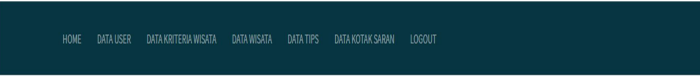

Data Kotak Saran

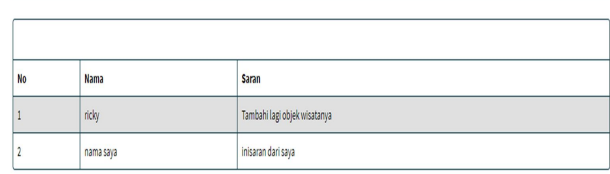

Gambar 13. Tampilan Halaman Data Kotak Saran

Halaman ini menampilkan saran - saran yang dikirim oleh pengguna dari aplikasi yang berisi tentang kekurangan dari aplikasi telah digunakan atau referensi tentang objek wisata yang belum terdaftar di aplikasi.
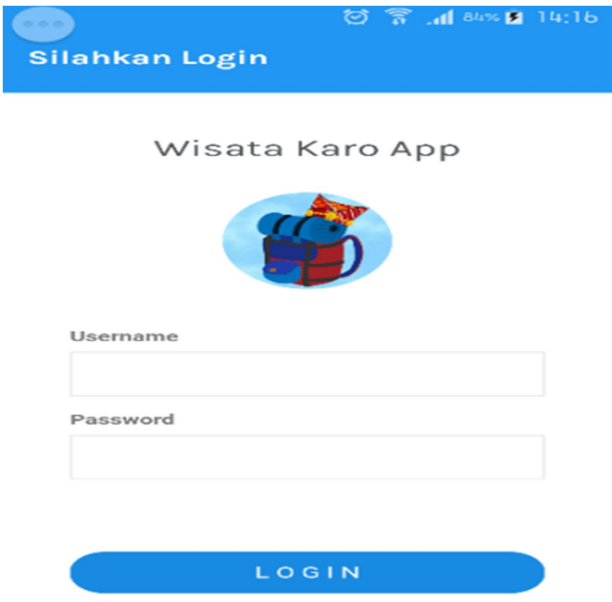

Gambar 14. Tampilan Halaman Login Aplikasi
Halaman ini merupakan halaman loginuser untuk masuk ke menu utama aplikasi. Jika user belum mendaftar sebagai pengguna aplikasi maka user dapat mendaftar dengan memilih tombol daftar.

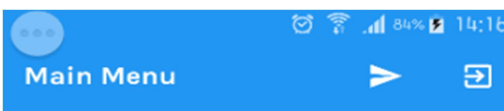

Wisata Karo App

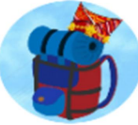

Mejuah - Juah, ANDRE6TEPU

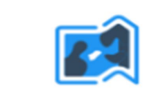

MAP Tanah Karo Klik Untuk Detail

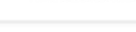
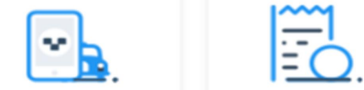

Perjalananku

Tips

\section{Gambar 15. Tampilan Halaman Menu Utama}

Halaman ini akan ditampilkan setelah user berhasil melakukan login. Pada halaman ini user dapat mengakses fitur - fitur yang terdapat pada aplikasi.

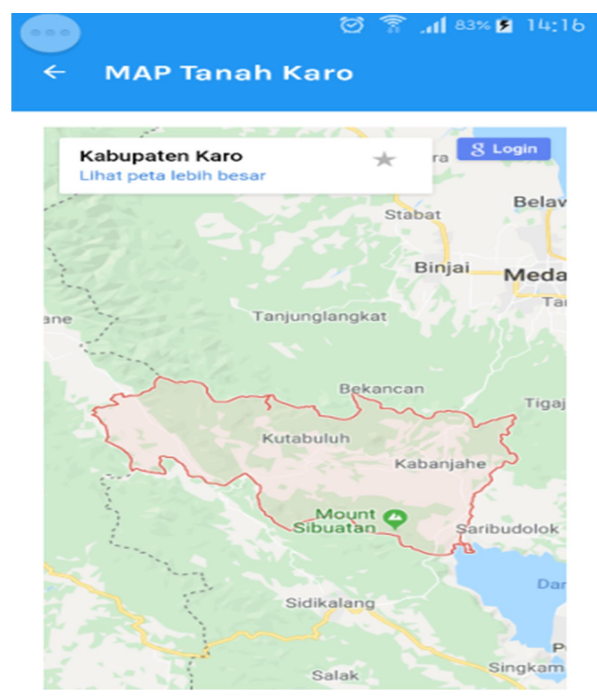

\section{Gambar 16. Tampilan Halaman Map Tanah Karo}

Pada halaman ini menampilkan lokasi Kabupaten Tanah Karo pada map sehingga diharapkan dapat membantu user dalam melihat lokasi Kabupaten Tanah Karo dengan lebih terperinci. 


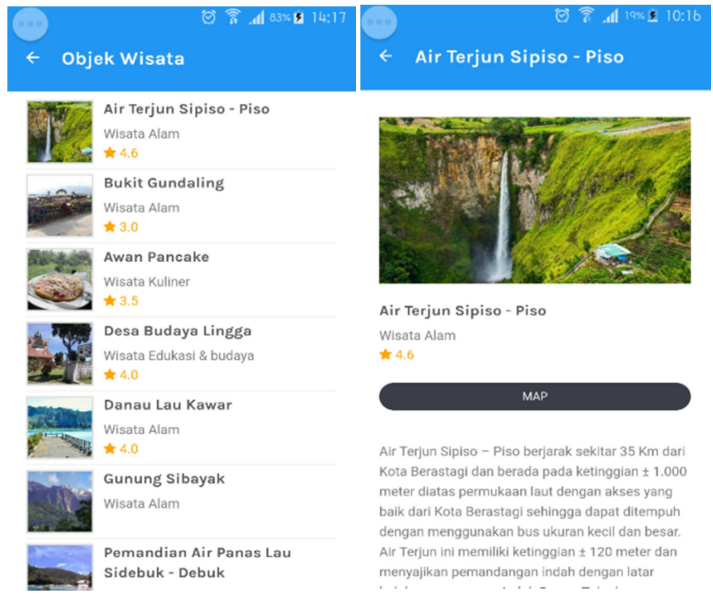

Gambar 17. Tampilan Halaman Objek Wisata

Halaman ini menampilkan objek - objek wisata yang dapat dikunjungi oleh user. Pada halaman ini user dapat melihat artikel tentang objek wisata yang diminati untuk dikunjungi dengan mengetuk objek wisata yang diminati serta melihat biaya masuk objek wisata, memberi penilaian tentang objek wisata, melihat penilaian yang diberikan user lainnya yang telah mengunjungi objek wisata tersebut dan meminta direksi panduan jalan menuju lokasi objek wisata dengan mengetuk tombol map.

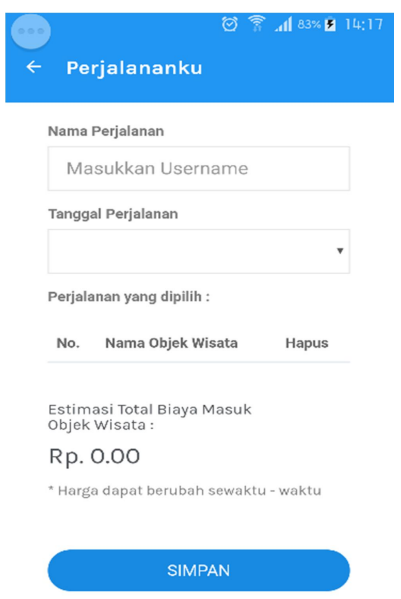

\section{Gambar 18. Tampilan Halaman Perjalananku}

Pada halaman ini akan menampilkan perencanaan perjalanan wisata ke Kabupaten Tanah Karo dengan terlebih dahulu menentukan nama dari perjalanan tersebut dan tanggal perjalanan. Setelah mengisi nama dan tanggal perjalanan maka user dapat memilih objek wisata apa saja yang ingin dikunjungi sehingga sistem dapat dengan otomatis menjumlahkan total biaya masuk untuk seluruh objek wisata yang akan dikunjungi sehingga diharapkan dapat membantu user dalam menyediakan biaya perjalanan dalam berwisata ke Kabupaten Tanah Karo.

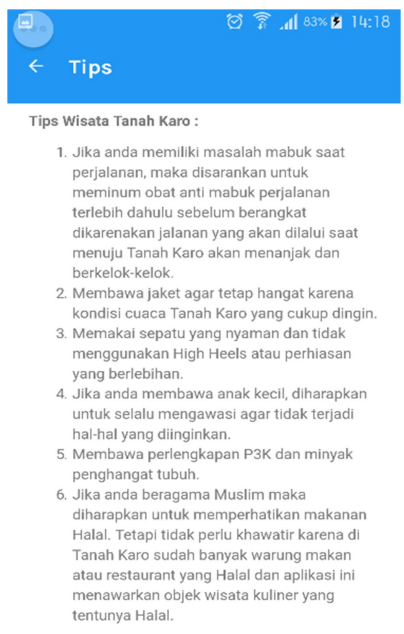

Gambar 19. Tampilan Halaman Tips

Halaman ini berisi saran untuk user yang akan melakukan perjalanan wisata ke Kabupaten Tanah Karo sehingga diharapkan dapat menghindari hal hal yang tidak diinginkan dan menikmati wisata dengan aman dan nyaman.

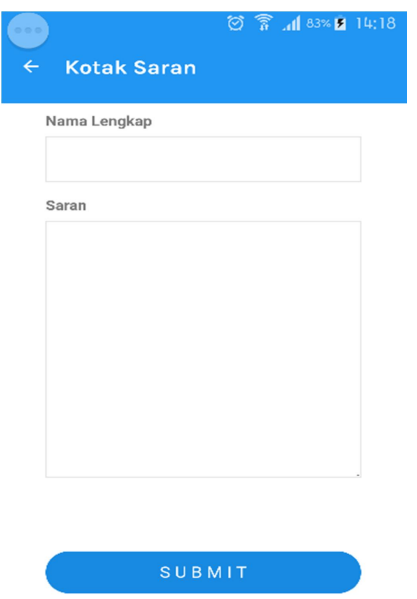

\section{Gambar 20. Tampilan Halaman Kotak Saran}

Pada halaman ini user dapat mengirimkan saran tentang aplikasi maupun referensi tentang objek wisata yang belum terdapat pada aplikasi.

\section{Kesimpulan}

\subsection{Kesimpulan}

Aplikasi dapat digunakan bagi user yang membutuhkan referensi objek wisata yang berada di Kabupaten. Aplikasi berjalan pada sistem operasi android dan user dapat menggunakan aplikasi di smartphone sehingga dapat digunakan dengan mudah dan aplikasi sudah menggunakan cloud 
database sehingga dapat menyimpan penilaian, saran dan menyimpan objek wisata yang ingin dikunjungi dengan menggunakan fitur Perjalananku.

\subsection{Saran}

Untuk pengembangan selanjutnya, aplikasi diharapkan dapat menyediakan fitur Bahasa Inggris sehingga turis mancanegara dapat menggunakan aplikasi dengan baik serta menambahkan informasi pendukung wisata lainnya seperti informasi tentang lokasi Anjungan Tunai Mandiri (ATM) dan informasi tentang lokasi hotel atau penginapan yang terdapat di Kabupaten Tanah Karo.

\section{DAFTAR PUSTAKA}

[1] Wawan Kurniawan ,'Dampak Sosial Ekonomi Pembangunan Pariwisata Umbul Sidomukti Kecamatan Bandungan Kabupaten Semarang”, Universitas Negeri Semarang, EDAJ Vol. 04, No. 04, 2015.

[2] Dinas Pariwisata dan Kebudayaan Kabupaten TanahKaro, Profil Kabupaten Tanah Karo, https://pariwisata.karokab.go.id/id/, 28 Maret 201920.05 WIB.

[3] Berita Resmi Statistik, Perkembangan Pariwisata dan Transportasi, https://karokab.bps.go.id/id/ , 28 Maret 201922.13 WIB.

[4] Shunfu Hu dan Ting Dai, “Online Map Application Development Using Google Maps API, SQL Database, and ASP.NET', Universitas Edwardsville, ICT Vol. 03, No. 03, 2013.

[5] Sri Murni, Latifah, Raja Sabrudin dan Yudhi L, "Penerapan Metode Waterfall Dalam Pembangunan Aplikasi Akuntansi Kontraktor Dengan Pemrograman PHP Studi Kasus : PT. Putranusa Pilar Sejati Pontianak", Universitas Bina Sarana Informatika Pontianak, JTI Vol. 11, No. 01, 2019.

[6]M. Diarmansyah Batubara and E. Indra, "Perencanaan dan Pembuatan Aplikasi Pengerjaan Ujian Nasional Tingkat SMP Berbasis Android," J. Sist. Inf., pp. 2579-5341, 2018.

[7]A. L. Sitanggang, M. Hati Loi, and E. Indra, "RANCANG BANGUN APLIKASI SISTEM UJIAN SARINGAN MASUK SMA BERBASIS ANDROID (Studi Kasus SMA Amir Hamzah Medan)," J. Sist. Inf. Ilmu Komput. Prima (JUSIKOM PRIMA), vol. 2, no. 2, 2019.

[8]E. Indra and M. Nababan, "APLIKASI PENDATAAN LOKASI BENGKEL RESMI SEPEDA MOTOR DI KOTA MEDAN BERBASIS ANDROID MENGGUNAKAN ALGORITMA FLOYD WARSHALL," J. Sist. Inf. Ilmu Komput. Prima (JUSIKOM PRIMA), vol. 1, no. 1, 2017. 